\section{SOURCES FOR TOLERANCE TO COLD IN CICER SPECIES}

\section{K. B. Singh, ${ }^{*}$ R. S. Malhotra, ANd M. C. SaXena}

\section{Abstract}

Cold tolerance is an important prerequisite for successful winter sowing of chickpea (Cicer arietinum L.). In the Mediterranean region, winter sowing will increase productivity compared with the same crop sown traditionally in the spring. In the search for germplasm possessing a higher level of tolerance to cold than the cultivated species, 137 lines of eight wild annual Cicer species were evaluated during the 1987-1988 and 1988-1989 seasons at the International Center for Agricultural Research in the Dry Areas (ICARDA), Syria. Both seasons were effective for screening chickpea against cold, as the susceptible indicator was killed by cold spells each year. Most of the lines of $C$. bijugum K.H. Rech., C. echinosperum P.H. Davis, and $C$. reticulatum Ladiz. were tolerant to cold and had significantly higher levels of cold tolerance than the cultivated species. All lines of $C$. chorassanicum (Bunge) M. Popov, $C$. cuneatum Hochst. ex Rich., and $C$. yamashitae Kitamura, and all but one line of $C$. judaicum Boiss., were susceptible. Lines of $C$. pinnatifidum Jaub. \& Spach showed both susceptible and tolerant reactions.

$\mathrm{W}$ ILD SPECIES have been exploited for the transfer of genes for stress resistance to the cultivated species in cereal crops, fiber crops, oilseeds, vegetables, and fruits. But, such use has not occurred in the cool-season food legumes (Ladizinsky et al., 1988), although genes for resistance to stresses have been identified in wild species. In Vicia species, accessions of $V$. johannis Tamamschjan and $V$. narbonensis $\mathrm{L}$. were resistant to black bean aphid (Aphis fabae Scopoli) and possessed improved frost tolerance (Birch, 1985). Resistance to rust [Uromyces vicia-fabae (Pers.) Schroet.] (Roupakias, 1986), chocolate spot (Botrytis fabae Sard.), and leaf blight (Ascochyta fabae Sard.) was found in $V$. narbonensis (Lawes et al., 1983). Among the Pisum species, Drozd (1981) reported heat and drought tolerance in $P$. fulvum Sibth. \& Smith.

In Cicer, eight wild annual and 34 wild perennial species are known (van der Maesen and Pundir, 1984). Annual Cicer species have been reported as sources of resistance to different stresses. For example, $C$. judaicum, C. montbrettii Jaub. \& Spach. and C. pinnatifidum possess genes for resistance to Ascochyta blight [Ascochyta rabiei (Pass.) Lab.] (K.B. Singh et al., 1981); C. judaicum to Fusarium wilt (Fusarium oxysporum f. sp. ciceris) (Nene and Haware, 1980); $C$. judaicum and C. pinnatifidum to gray mold (Botrytis cinerea Pers. ex Fr.) (G. Singh et al., 1982); and $C$. bijugum to Heterodera ciceri (K.B. Singh et al., 1989a).

At ICARDA, intensive efforts are underway to breed cold- and Ascochyta blight-resistant chickpea cultivars suitable for winter sowing in the Mediterranean region. Chickpea is traditionally spring-sown, but win-

Food Legume Improvement Program, Int. Ctr. for Agric. Res. in the Dry Areas (ICARDA), P.O. Box 5466, Aleppo, Syria. Joint contribution from ICARDA and ICRISAT (Int. Crops Res. Inst. for the Semi-Arid Tropics), Patancheru P.O., A.P. 502 324, India. Received 7 Nov. 1989. *Corresponding author.

Published in Crop Sci. 30:1136-1138 (1990). ter sowing has the potential for nearly doubling the seed yield (K.B. Singh, 1988). Yield is increased after winter sowing because of better water-use efficiency and more favorable temperatures than after spring sowing. Several thousand lines of garbanzo or kabulitype chickpea (characterized by large ramheadshaped, beige-colored seeds) have been evaluated for cold tolerance, and moderately tolerant lines have been identified (K.B. Singh et al., 1989b). ICARDA holds 137 accessions representing the eight wild annual Cicer species. These were evaluated for cold tolerance, and the results are reported here.

\section{Materials and Methods}

The 137 accessions of eight wild Cicer species consisted of 23 C. bijugum, five C. chorassanicum, three $C$. cuneatum, four C. echinospermum, 47 C. judaicum, 30 C. pinnatifidum, 23 C. reticulatum, and two C. yamashitae. These accessions were sown in a randomized complete block design with two replications on 20 Oct. 1987 at Tel Hadya (ICARDA's principal research station), Syria $\left(36^{\circ} 01^{\prime} \mathrm{N}, 36^{\circ} 56^{\prime} \mathrm{E}, 284 \mathrm{~m}\right.$ elevation). Each accession was sown in single-row plots $2 \mathrm{~m}$ long with inter- and intra-row spacing of 45 and $10 \mathrm{~cm}$, respectively. The susceptible indicator rows of ILC 533 of cultivated species were sown every fifth plot. In addition, a tolerant check (ILC 3465) of the cultivated species was sown. Irrigation $(40 \mathrm{~mm})$ was applied at planting to ensure rapid emergence, followed by two more irrigations of $50 \mathrm{~mm}$ each to ensure moisture supply until rain came in late November. The crop was prótected from Ascochyta blight by periodic spraying of the fungicide chlorothalonil (tetrachloroisophthalonitrile) at the rate of $0.8 \mathrm{~kg}$ a.i. per hectare. The experimental area was hand-weeded.

Visual cold-tolerance ratings on a scale of 1 to 9 were assigned after the susceptible check was killed. Ratings followed the scale described by K.B. Singh et al. (1989b), where $1=$ no visible symptoms of damage; $2=$ highly tolerant ( $\leq 10 \%$ of leaflets show withering and drying; no killing); 3 $=$ tolerant $(11-20 \%$ of leaflets show withering; $\leq 20 \%$ of branches show withering and drying; no killing); $4=$ moderately tolerant $(21-40 \%$ of leaflets and $\leq 20 \%$ of branches show withering and drying; no killing); $5=$ intermediate (41-60\% of leaflets and $21-40 \%$ of branches show withering and drying; $\leq 5 \%$ plant killing); $6=$ moderately susceptible (61-80\% of leaflets and $41-60 \%$ of branches show withering and drying; 6-25\% plant killing); $7=$ susceptible ( $81-99 \%$ of leaflets and $61-80 \%$ of branches show withering and drying; $26-50 \%$ plant killing); $8=$ highly susceptible $(100 \%$ of leaflets and $81-99 \%$ of branches show withering and drying; $51-99 \%$ plant killing); and $9=100 \%$ plant killing.

For reconfirmation of cold tolerance reaction of the accessions, the experiment was repeated in the 1988-1989 season. Sowing was done on 30 Sept. 1988, and design and management practices were the same as in 1987-1988. In this season, observations on resistant lines for growth habit, leaflet area, days to flowering, plant height, and 100-seed weight were also recorded. The higher rating of the two seasons was considered as the actual cold tolerance rating of the lines.

Welch's $t$-test (1938) was used to compare the means of any two wild Cicer species; C. yamashitae was not considered for comparison, as it revealed only one degree of freedom.

Weather data on the number of days with freezing temperatures, monthly mean minimum temperature, and absolute minimum temperature were recorded for the two seasons.

\section{Results and Discussion}

Both the seasons were effective for screening material for cold tolerance, as the susceptible check was 
Table 1. Number of days with freezing temperatures (DFT), the minimum mean monthly temperature (MMMT), and the absolute minimum monthly temperature (AMMT) for two chickpea crop seasons at Tel Hadya, Syria.

\begin{tabular}{|c|c|c|c|c|c|c|}
\hline \multirow[b]{2}{*}{ Month } & \multicolumn{3}{|c|}{$1987-1988$} & \multicolumn{3}{|c|}{$1988-1989$} \\
\hline & DFT & MMMT & AMMT & DFT & MMMT & AMMT \\
\hline
\end{tabular}

\begin{tabular}{|c|c|c|c|c|c|c|}
\hline October & 0 & 11.4 & 3.8 & 0 & 12.2 & 4.8 \\
\hline November & 0 & 5.1 & 0.2 & 4 & 4.6 & -6.6 \\
\hline December & 4 & 5.3 & -7.4 & 5 & 2.6 & -4.5 \\
\hline January & 8 & 2.1 & -2.2 & 22 & -2.3 & -9.7 \\
\hline February & 7 & 4.0 & -2.4 & 18 & -1.4 & -9.9 \\
\hline March & 2 & 5.1 & -2.8 & 2 & 6.1 & -1.1 \\
\hline April & 0 & 8.0 & 0.4 & 0 & 9.8 & 2.9 \\
\hline May & 0 & 12.4 & 5.8 & 0 & 12.8 & 7.7 \\
\hline June & 0 & 17.3 & 12.8 & 0 & 17.4 & 12.2 \\
\hline
\end{tabular}

Table 3. Comparison of mean cold reaction of eight wild and one cultivated Cicer species, based on Welch's $t$-test.

\begin{tabular}{cccccccccc}
\hline \multicolumn{10}{c}{ Cicer speciest } \\
\cline { 2 - 10 } & $\mathrm{C}_{1}$ & $\mathrm{C}_{2}$ & $\mathrm{C}_{3}$ & $\mathrm{C}_{4}$ & $\mathrm{C}_{5}$ & $\mathrm{C}_{6}$ & $\mathrm{C}_{7}$ & $\mathrm{C}_{8}$ & $\mathrm{C}_{9}$ \\
\hline $\mathrm{C}_{1}$ & $2.087 \ddagger$ & $* *$ & $* *$ & $* *$ & $* *$ & $* *$ & $* *$ & $\mathrm{NT}$ & $* *$ \\
$\mathrm{C}_{2}$ & & 7.400 & $*$ & $* *$ & $* *$ & $* *$ & $* *$ & $\mathrm{NT}$ & $\mathrm{NS}$ \\
$\mathrm{C}_{3}$ & & & 9.000 & $* *$ & $* *$ & $* *$ & $* *$ & $\mathrm{NT}$ & $* *$ \\
$\mathrm{C}_{4}$ & & & & 3.750 & $* *$ & $* *$ & $\mathrm{NS}$ & $\mathrm{NT}$ & $* *$ \\
$\mathrm{C}_{5}$ & & & & & 8.511 & $* *$ & $* *$ & $\mathrm{NT}$ & $* *$ \\
$\mathrm{C}_{6}$ & & & & & & 5.600 & $* *$ & $\mathrm{NT}$ & $* *$ \\
$\mathrm{C}_{7}$ & & & & & & & 3.478 & NT & $* *$ \\
$\mathrm{C}_{8}$ & & & & & & & & 6.500 & NT \\
$\mathrm{C}_{9}$ & & & & & & & & & 7.570 \\
\hline
\end{tabular}

*** Significant at the 0.05 and 0.01 probability levels, respectively; NS = not significant; $\mathrm{NT}=$ not tested.

$+\mathrm{C}_{1}$ to $\mathrm{C}_{9}$ represent Cicer species as listed in order in Table 2; the cultivated species is $\mathrm{C}_{9}$.

$\ddagger$ Diagonal values are mean scores for individual species.

Table 2. Reaction of eight wild annual Cicer species to cold at Tel Hadya, Syria, during 1987-1988 and 1988-1989, with comparison to cultivated chickpea. $\dagger$

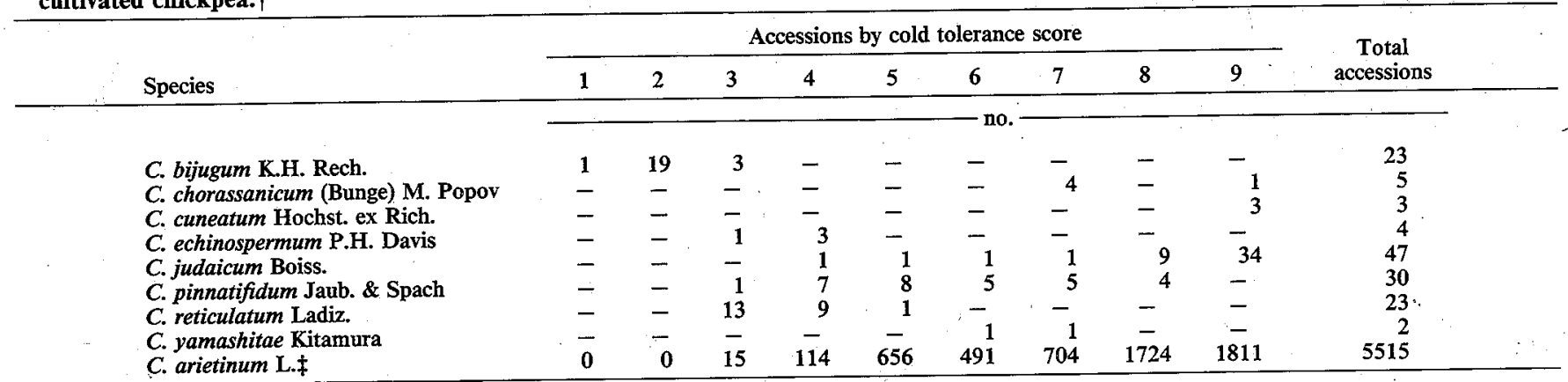

The higher rating of the two years was taken as the rating; $1=$ no visible damage, $9=$ killed.

$\ddagger$ Source: K.B. Singh (1989).

killed both times. But, the absolute minimum temperature was lower and the number of frosty days higher during 1988-1989 than 1987-1988 (Table 1).

Cold tolerance reaction of wild Cicer species is given in Table 2. For the sake of comparison, the results of the screening of accessions of $C$. arietinum to cold already reported by K.B. Singh (1989) are also presented in the same table. Analysis following Welch's $t$-test is presented in Table 3 . The comparison of mean cold reaction of different wild Cicer species with the cultivated species ( $C$. arietinum) revealed that the level of tolerance in $C$. bijugum, $C$. echinospermum, $C$. reticulatum, and $C$. pinnatifidum was significantly superior; in $C$. cuneatum and $C$. judaicum, it was significantly inferior; and in $C$. chorassanicum, it was equal to the cultivated species. Virtually all lines of $C$. bijugum, C. echinospermum, and $C$. reticulatum were tolerant to cold, and all lines of $C$. chorassanicum, C. cuneatum, and C. yamashitae were susceptible. One line of $C$. judaicum and eight lines of $C$. pinnatifidum were tolerant to cold and the remaining lines were susceptible. The evaluation revealed large inter- and intraspecies variations in cold tolerance. Further, the comparison of tolerant species among themselves revealed that $C$. bijugum had the highest level of tolerance and was closely followed by $C$. reticulatum and C. echinospermum.

The 1988-1989 season at Tel Hadya was the coldest in the past 30 years, and the lines of cultivated species that consistently rated as tolerant (rating 3 ) in previous screenings from $1981-1982$ to $1987-1988$ were rated moderately tolerant (rating 4). Our results fur- ther emphasize that the level of cold tolerance is higher in certain wild species than in the cultivated species.

Except for crosses with $C$. reticulatum, all previous attempts to cross $C$. arietinum with other species have failed to produce fertile $F_{1}$ plants (Ladizinsky and Alder, 1976). We have crossed four lines of cultivated species with one tolerant line of $C$. reticulatum with the objective of transferring the gene(s) for tolerance to cold.

Growth habit, leaflet area, days to flowering, plant height, and 100-seed weight of each cold-tolerant line (rating 1-3) are shown in Table 4. All of them had spreading growth habit, small leaflet size, dwarf plant stature, small seed size, and medium to late maturity. Since none of these characters is desirable for commercial chickpea, efforts will be made to transfer gene(s) for cold tolerance to the cultivated species through the backcross method.

\section{Acknowledgments}

The technical assistance of Messrs. B. Ocampo, G. Khalaf and Rafat Azzo is gratefully acknowledged.

\section{References}

Birch, N. 1985. Field evaluation of resistance to black bean aphid, Aphis fabae, a close relative of the faba bean, Vicia faba. Ann. Appl. Biol. 106:561-569.

Drozd, A. M. 1981. Use of Pisum fulvum Sibth. et Smith in breeding pea varieties of the garden type. (In Russian.) Tr. Prikl. Bot. Genet. Sel. 70:33-35.

Ladizinsky, G., and A. Adler, 1976. Genetic relationships among the annual species of Cicer L. Theor. Appl. Genet. 48:197-203. Ladizinsky, G., B. Pickergill, and K. Yamamoto. 1988. Exploitation 
Table 4. Observations on selected characteristics recorded on cold-tolerant Cicer species at Tel Hadya, Syria, 1988-1989.

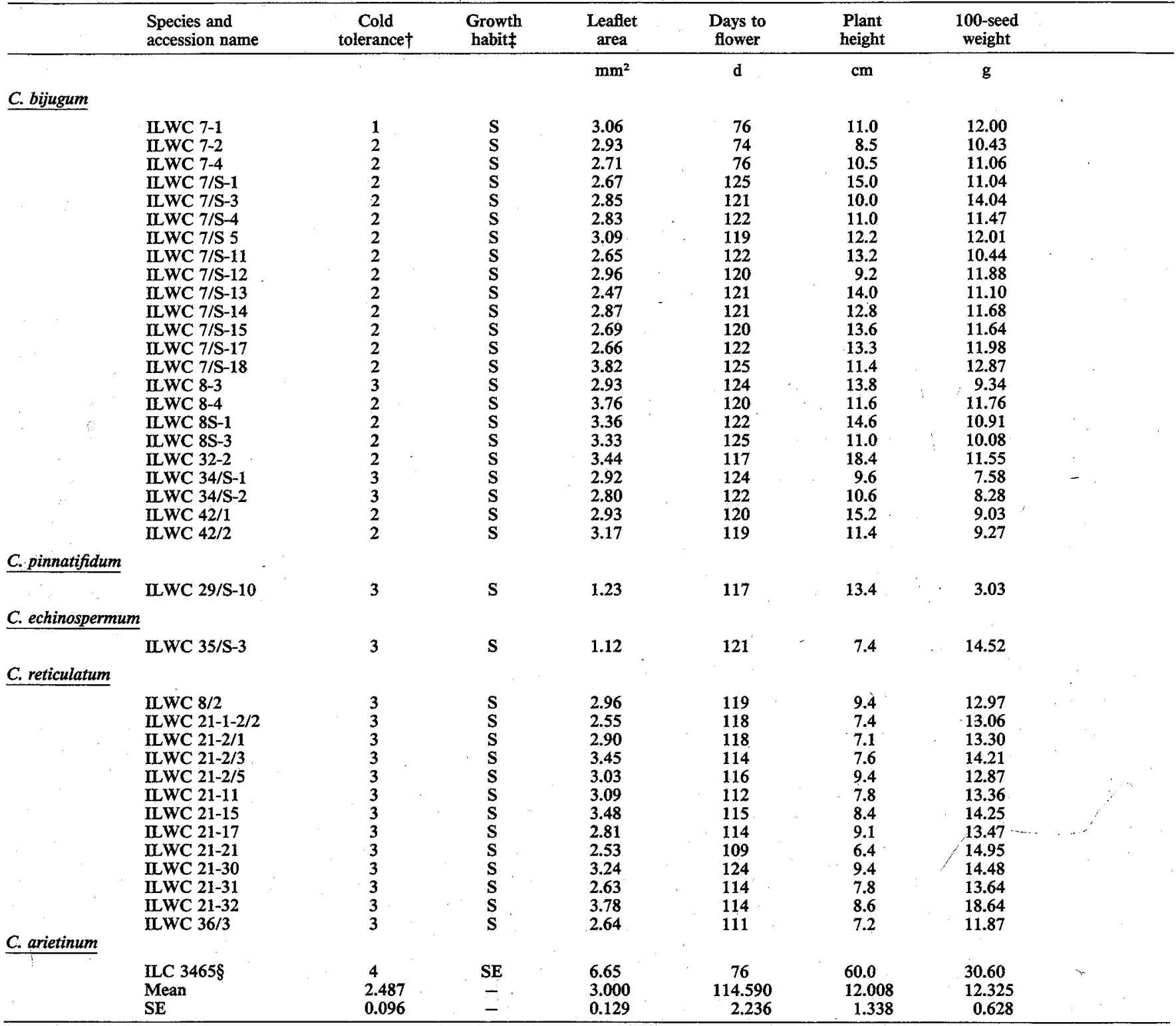

† Scale of 1 to 9 , where $1=$ no visible damage; 2 = highly tolerant (no killing; $\leq 10 \%$ of leaflets show withering and drying); $3=$ tolerant (no killing; $11-21 \%$ of leaflets show withering, $\leq 20 \%$ of branches show withering and drying); and $4=$ moderately tolerant (no killing; $21-40 \%$ of leaflets and branches show withering and drying); $5=$ intermediate; 6,7 , and $8=$ increasingly susceptible; and $9=100 \%$ plant killing.

$\ddagger \mathrm{S}=$ spreading, $\mathbf{S E}=$ semi-erect.

\& ILC 3465 (C. arietinum) is included for comparison with wild species.

of wild relatives of the food legumes. p. 967-978. In R.J. Summerfield (ed.) World crops: Cool season food legumes. Kluwer Academic Publ., Dordrecht, Netherlands.

Lawes, D. A., D. A. Bond, and M. H. Poulsen. 1983. Classification, origin, breeding methods, and objectives. p. 591-611. In P. D. Hebblethwaite (ed.) The faba bean (Vicia faba L.). Butterworths, London.

Nene, Y. L., and M. P. Haware. 1980. Screening chickpea for resistance to wilt. Plant Dis. 64:379-380.

Roupakias, D. G. 1986. Interspecific hybridization between Vicia $f a b a(\mathrm{~L}$.) and Vicia narbonensis (L.): Early pod growth and embryo-sac development. Euphytica 35:175-183.

Singh, G., S. Kapoor, and K. Singh. 1982. Screening chickpea for gray mold resistance. Int. Chickpea Newsl. 7:13-14.

Singh, K. B. 1988. Winter chickpea: Problems and potentials in the Mediterranean region. CIHEAM (Ctr. Int. de Hautes Etudes Agronomiques Mêditerranéennes) conference on present status and future prospects of chickpea crop production and improvement in the Mediterranean countries, Zaragoza, Spain. 11-13 July
1988.

Singh, K. B. 1989. Breeding chickpea (Cicer arietinum L.) for multiple stress resistance. Proc. 6th Int. Congr. SABRAO (Soc. for the Adv. of Breeding Res. in Asia and Oceania). p. 237-240.

Singh, K. B., M. Di Vito, N. Greco, and M. C. Saxena. 1989a. Reaction of wild Cicer spp. lines to Heterodera ciceri. Nematologia Mediterranean 17:113-114.

Singh, K. B., G. C. Hawtin, Y.L. Nene, and M. V. Reddy. 1981. Resistance in chickpea to Ascochyta rabiei. Plant Dis. 65:586587.

Singh, K. B., R. S. Malhotra, and M. C. Saxena. 1989b. Chickpea evaluation for cold tolerance under field conditions. Crop Sci. 29:282-285.

van der Maesen, L. J. G., and R. P. S. Pundir. 1984. Availability and use of wild Cicer germplasm. Plant Genet. Resour. Newsi. 57:19-24.

Welch, B. L. 1938. The significance of the difference between two means when population variances are unequal. Biometrika $29: 350-362$. 